\title{
Challenges for Present and Future Estimates of Anthropogenic Carbon in the Indian Ocean
}

\author{
C. Goyet and F. Touratier
}

IMAGES, Université de Perpignan, Perpignan, France

\begin{abstract}
One of the main challenges we face today is to determine the evolution of the penetration of anthropogenic $\mathrm{CO}_{2}$ into the Indian Ocean and its impacts on marine and human life. Anthropogenic $\mathrm{CO}_{2}$ reaches the ocean via air-sea interactions as well as riverine inputs. It is then stored in the ocean and follows the oceanic circulation. As the carbon dioxide from the atmosphere penetrates into the sea, it reacts with water and acidifies the ocean. Consequently, the whole marine ecosystem is perturbed, thus potentially affecting the food web, which has, in turn, a direct impact on seafood supply for humans. Naturally, this will mainly affect the growing number of people living in coastal areas. Although anthropogenic $\mathrm{CO}_{2}$ in the ocean is identical with natural $\mathrm{CO}_{2}$ and therefore cannot be detected alone, many approaches are available today to estimate it. Since most of the results of these methods are globally in agreement, here we chose one of these methods, the tracer using oxygen, total inorganic carbon, and total alkalinity (TrOCA) approach, to compute the 3-D distribution of the anthropogenic $\mathrm{CO}_{2}$ concentrations throughout the Indian Ocean. The results of this distribution clearly illustrate the contrast between the Arabian Sea and the Bay of Bengal. They further show the importance of the southern part of this ocean that carries some anthropogenic $\mathrm{CO}_{2}$ at great depths. In order to determine the future anthropogenic impacts on the Indian Ocean, it is urgent and necessary to understand the present state. As the seawater temperature increases, how and how fast will the ocean circulation change? What will the impacts on seawater properties be? Many people are living on the bordering coasts, how will they be affected?
\end{abstract}

\section{INTRODUCTION}

The Indian Ocean is a very complex system with a highly variable water circulation mainly constrained by monsoon winds [Schott and McCreary, 2001]. For instance, the winds force the Somali Current to reverse direction seasonally. As a result, it is extremely difficult to determine the impact of

Indian Ocean Biogeochemical Processes and Ecological Variability Geophysical Monograph Series 185

Copyright 2009 by the American Geophysical Union. 10.1029/2008GM000754 this complex and seasonally changing water circulation on its biogeochemical properties. On top of this natural complexity, human activities provoke a rapid seawater temperature increase. Thus, additional unknowns are added concerning the future evolution of marine biota, of biogeochemical properties, and of carbon uptake.

The Indian Ocean is smaller than both the Atlantic and Pacific oceans. Yet it plays a significant role in the absorption of anthropogenic carbon. The latter is stored in the Indian Ocean via three key processes:

1. Red Sea-Persian Gulf Intermediate Water is formed in the northwestern Indian Ocean, [Papaud and Poisson, 1986; 
Mecking and Warner, 1999]. This water then flows southward (equatorward).

2. Subantarctic Mode Water (SAMW) [Sloyan and Rintoul, 2001; Sallée et al., 2006] is formed in the southeastern Indian Ocean north of the Subantarctic Front [McCartney, 1977]. This water then flows northward (equatorward) at around 400-600 $\mathrm{m}$ depth.

3. Antarctic Intermediate Water (AAIW) is formed in the Southern Ocean. The AAIW in the South Indian Ocean (and the South Atlantic) is formed in the confluence of the Malvinas and Brazil currents by injection of surface water into the subtropical gyre. Then it flows eastward and northward in these ocean basins, where no other sources of anthropogenic carbon are found [Talley, 1996; Hanawa and Talley, 2001].

In theory, another major pathway of anthropogenic $\mathrm{CO}_{2}$ $\left(C_{\mathrm{ANT}}\right)$ penetration into the Indian Ocean should be the formation of Antarctic Bottom Water (AABW). However, there are still large discrepancies among various estimates of $C_{\mathrm{ANT}}$ uptake and storage in the AABW. Results from models and early estimates [Poisson and Chen, 1987; Gruber, 1998; Hoppema et al., 2001] indicated a relatively poor penetration of $C_{\mathrm{ANT}}$. This could be explained by limited contact of the surface seawater with the atmosphere because of the ice cover, thus leading to a reduced $\mathrm{CO}_{2}$ uptake before sinking down into the ocean interior.

However recent studies indicate both a CFC accumulation in Antarctic deep and bottom waters [e.g., Meredith et al., 2001; Orsi et al., 2002] and a $C_{\mathrm{ANT}}$ accumulation south of Australia [McNeil et al., 2007], as well as in deep and bottom waters of the Southern Ocean [Lo Monaco et al., 2005a; Sandrini et al., 2007].

Overall, the Arabian Sea is known as a $\mathrm{CO}_{2}$ source for the atmosphere since during the southwest monsoon; the upwelling brings cold and $\mathrm{CO}_{2}$-rich waters to the surface. As they warm in contact with the atmosphere, their $p \mathrm{CO}_{2}$ rises further, well above the atmospheric level in spite of the concurrent phytoplankton blooms, thus providing a significant source of $\mathrm{CO}_{2}$ to the atmosphere [Millero et al., 1998; Goyet et al., 1998; Naqvi et al., 2005].

In contrast, over a year, the Bay of Bengal with its relatively cool water is probably a $\mathrm{CO}_{2}$ sink for the atmosphere. Some data indicate that this basin could be alternatively a $\mathrm{CO}_{2}$ source or a $\mathrm{CO}_{2}$ sink throughout the year depending on the seasons. Unfortunately, data in this area are still too scarce [Bates et al., 2006] to determine the mean annual $\mathrm{CO}_{2}$ flux in this area.

In the South Indian Ocean, including the Indian segment of the Southern Ocean, time series measurements of $p \mathrm{CO}_{2}$ in surface waters indicate that this sea is a $\mathrm{CO}_{2}$ sink, the strength of which decreases with time [Goyet et al., 1991; Metzl et al., 1991; Brévière et al., 2006]. This trend is prob- ably due to both the increase of atmospheric $\mathrm{CO}_{2}$ partial pressure and the decreasing buffer capacity of the ocean.

Consequently, as a whole, the Indian Ocean is considered as a significant $\mathrm{CO}_{2}$ sink for the atmosphere. Yet the strength of this $\mathrm{CO}_{2}$ sink seems to be decreasing with time. In the current context of the anthropogenic carbon rise in the atmosphere, these observations raise further concerns: How much anthropogenic carbon will the Indian Ocean continue to absorb? And at what pace? In order to be able to answer these questions, one should know both the present distribution of anthropogenic carbon in the Indian Ocean and the past and future water mass properties and circulation.

\section{DISTRIBUTION OF ANTHROPOGENIC CARBON IN THE INDIAN OCEAN}

Since anthropogenic carbon in the ocean cannot be measured directly, it is calculated according to various models based upon different assumptions. Although the early attempts to estimate the distribution of anthropogenic carbon in the ocean [Brewer, 1978; Chen and Millero, 1979] were criticized [Shiller, 1981; Broecker et al., 1985], they initiated a large and long debate concerning the "best way" to determine the distribution of anthropogenic $\mathrm{CO}_{2}$ in the ocean.

Since then, many different methods arose. Many are still based on the initial work of the late 1970s with various improvements (e.g., $\Delta C^{*}$ approach of Gruber et al. [1996]; Pérez et al. [2002]; and LM approach of Lo Monaco et al. [2005a]). Others use completely new concepts such as water mass mixing [Goyet et al., 1999], similarity with CFCs or $\mathrm{SF}_{6}$ penetration [e.g., Goyet and Brewer, 1993], the transit time distribution (TTD) approach of Waugh et al. [2004, 2006] and Tanhua et al. [2008], or a new water mass tracer "TrOCA" [Touratier and Goyet, 2004a, 2004b; Touratier et al., 2007].

Today, in order to better understand the processes of anthropogenic $\mathrm{CO}_{2}$ penetration into the ocean, many studies are comparing the results of these various approaches based on data [Coatanoan et al., 2001; Lo Monaco et al., 2005b; Friis, 2006; Touratier et al., 2007; Vázquez-Rodríguez et al., 2009]. Other studies compare results of anthropogenic carbon estimates with those based on ocean circulation models [Wanninkhof et al., 1999; Mikaloff-Fletcher et al., 2006; Orr et al., 2001; Gerber et al., 2009].

On a global average, the results of each of these methods are roughly similar. However, locally, the differences of the anthropogenic distribution among various approaches can be quite large (by a factor of 2). Yet, in spite of the recent results comparisons, without an absolute reference for the quantification of anthropogenic carbon in the ocean, it is 
extremely difficult to gain a complete understanding of all the hypotheses of each method and therefore to recommend the use of one method over another.

Nevertheless, a few patterns start to emerge. For instance, several studies in the Indian and the Atlantic oceans [Coatanoan et al., 2001; Vázquez-Rodríguez et al., 2009] indicate that the $\Delta C^{*}$ approach induces a strong anthropogenic $\mathrm{CO}_{2}$ discontinuity at mid depth (where the distribution of CFCs comes close to zero), which is not seen in any other method.

The use of only CFCs to estimate anthropogenic $\mathrm{CO}_{2}$ (such as the TTD approach) presents the advantage of being relatively simple, but it is limited to water masses younger than 1950 since CFCs did not exist prior to that time.

In order to use the water mass mixing method, one needs an excellent knowledge of the various water masses involved. The method provides great detail over an ocean section. However, it is relatively difficult to apply it over an entire ocean basin.

All methods based upon the initial work of the late 1970s require an estimate of preformed (before 1900) concentrations of total alkalinity and total $\mathrm{CO}_{2}$. These estimates often differ from one author to another and are extremely difficult to validate. In addition, these anthropogenic $\mathrm{CO}_{2}$ estimates rely on constant Redfield ratios, for which the appropriate values are still debated. Thus, for unclear reasons, it seems as though each author uses a different value for these ratios. Consequently, it is extremely difficult to objectively determine which of the various proposed improvements is significant. For instance, the LM approach seems to provide reasonable distribution patterns but with relatively high concentrations of anthropogenic carbon.

The simplest approach of all that seems to work relatively well everywhere (as judged by reasonable distribution patterns and concentrations) is the TrOCA method. It can be easily applied to an ocean section, as well as an ocean basin. (It could also simply be introduced into 3-D ocean models.) The method also relies upon a Redfield ratio. However, here it has objectively been determined using the international global GLODAP data set [Key et al., 2004].

The first global estimate of anthropogenic carbon distribution in the Indian Ocean [Chen, 1993] indicated that this ocean contains about $21 \%$ of the anthropogenic carbon stored in the sea. A few years ago, Sabine et al. [2004] further confirmed this estimate. However, the precise distribution of anthropogenic carbon within the Indian Ocean still needs to be determined.

Of course, the debate concerning "the best" method to use in order to quantify the anthropogenic $\mathrm{CO}_{2}$ in the ocean is still vigorous. Yet the scientific community has never been so close to unraveling this issue. It is only when two or more, different methods provide the same results that one can vali- date the accuracy of the particular approach. Today, several methods exist. They may just need a little tuning (e.g., applying the same Redfield ratios, etc.) for their results to come into agreement.

Nevertheless, Plate 1 illustrates the broad characteristics of the anthropogenic $\mathrm{CO}_{2}$ distribution in the Indian Ocean as it is calculated using the TrOCA method with the Indian Ocean data extracted from the GLODAP data set.

Plate 1a shows the distribution of anthropogenic $\mathrm{CO}_{2}$ at a depth of $250 \mathrm{~m}$ throughout the Indian Ocean. At this depth, there is almost twice as much anthropogenic $\mathrm{CO}_{2}$ in the Arabian Sea $\left(\sim 33 \mu \mathrm{mol} \mathrm{kg}^{-1}\right)$ as in the Bay of Bengal $(\sim 17 \mu \mathrm{mol}$ $\left.\mathrm{kg}^{-1}\right)$, and there is almost twice as much $\left(\sim 53 \mu \mathrm{mol} \mathrm{kg}{ }^{-1}\right)$ anthropogenic $\mathrm{CO}_{2}$ east of $80^{\circ} \mathrm{E}$ in the latitudinal zone between $25^{\circ} \mathrm{S}$ and $50^{\circ} \mathrm{S}$ than in the Arabian Sea. South of $55^{\circ} \mathrm{S}$, the concentration of anthropogenic $\mathrm{CO}_{2}\left(\sim 15 \mu \mathrm{mol} \mathrm{kg}{ }^{-1}\right)$ is relatively homogeneous and close to that of the Bay of Bengal. The green zonal band between about $10^{\circ} \mathrm{S}$ and $20^{\circ} \mathrm{S}$ reflects the role of the Indonesian Throughflow water (see also Plate $1 b)$.

At $700 \mathrm{~m}$ depth, Plate $1 \mathrm{~b}$ still illustrates similar characteristics of the anthropogenic $\mathrm{CO}_{2}$ distribution as above (at $250 \mathrm{~m}$ ) but with concentrations decreased roughly by a factor of 2 .

At $1200 \mathrm{~m}$ depth (Plate 1c), it is interesting to see that the anthropogenic $\mathrm{CO}_{2}$ has not penetrated much either north of $20^{\circ} \mathrm{S}$ or south of $55^{\circ} \mathrm{S}$. It is essentially concentrated in the latitudinal band between $25^{\circ} \mathrm{S}$ and $50^{\circ} \mathrm{S}$, where it reaches $\sim 25 \mu \mathrm{mol} \mathrm{kg}{ }^{-1}$.

At $3000 \mathrm{~m}$ depth, the Indian Ocean is pretty much anthropogenic carbon-free except south of $55^{\circ} \mathrm{S}$ in the Indian sector of the Antarctic Ocean where the $C_{\mathrm{ANT}}$ concentrations are around $11 \mu \mathrm{mol} \mathrm{kg}{ }^{-1}$.

The core message is that even if the Arabian Sea is a source of $\mathrm{CO}_{2}$ for the atmosphere and the Bay of Bengal is a potential $\mathrm{CO}_{2}$ sink for the atmosphere, there is about twice as much anthropogenic $\mathrm{CO}_{2}$ in the Arabian Sea as in the Bay of Bengal concentrated in the upper $1200 \mathrm{~m}$. Furthermore, the concentration of anthropogenic $\mathrm{CO}_{2}$ in the Southern Ocean south of the Indian Ocean is close to $10 \mu \mathrm{mol} \mathrm{kg}{ }^{-1}$ throughout the water column, even below $3000 \mathrm{~m}$ depth.

In other words, the Indian Ocean is a very complex area where ocean circulation and physical forcings play an extremely important role both in sequestering the anthropogenic $\mathrm{CO}_{2}$ and in releasing it to the atmosphere. Here the contrast between the Arabian Sea and the Bay of Bengal clearly illustrates that the $\mathrm{CO}_{2}$ from the $\mathrm{CO}_{2}$ fluxes across the ocean-atmosphere interface may not be directly transported vertically down into (or up from) the water column. Horizontal water circulation is the main process carrying anthropogenic $\mathrm{CO}_{2}$ from one area to another. Therefore, if we 

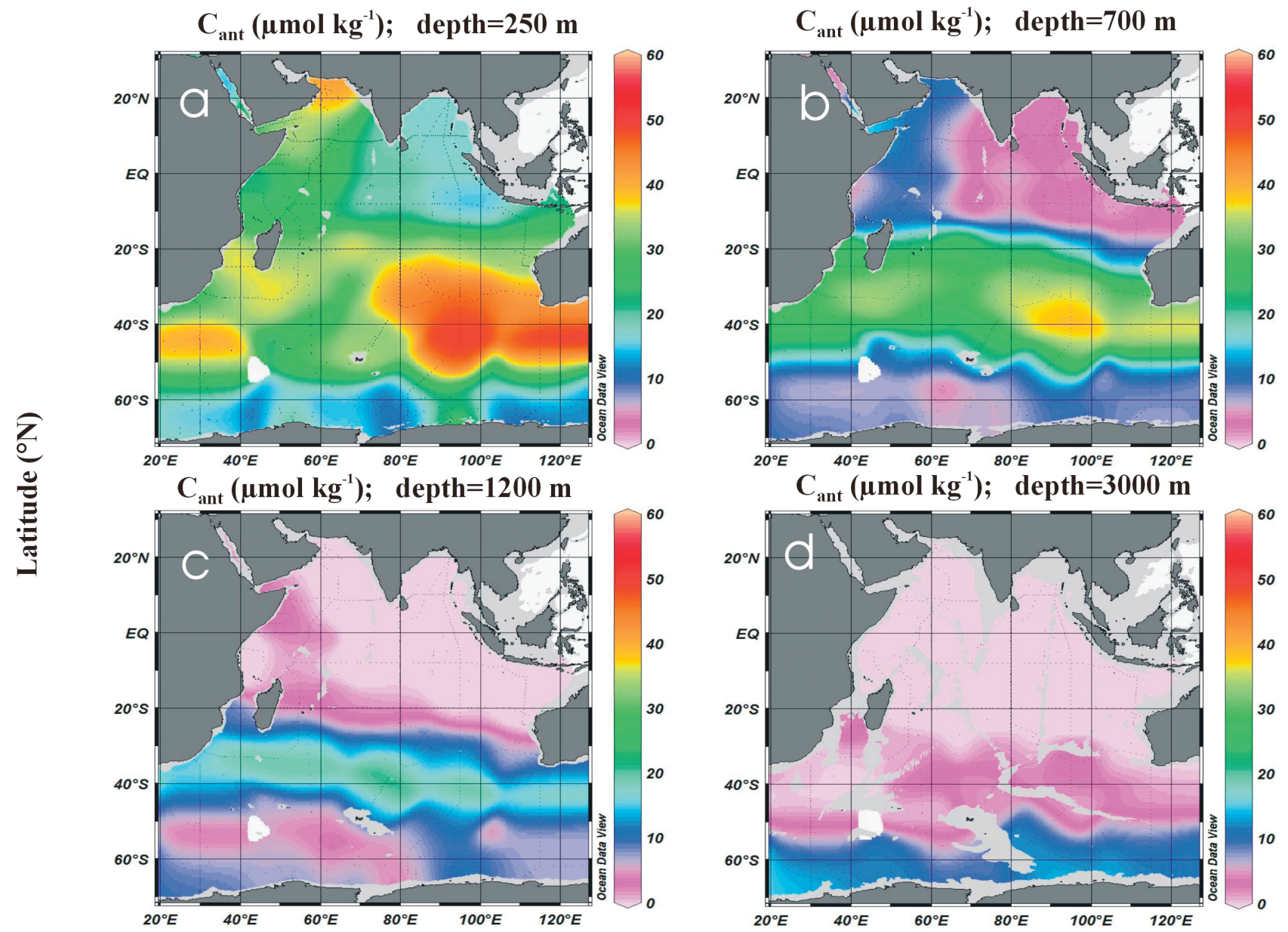

\section{Longitude $\left({ }^{\circ} \mathrm{E}\right)$}

Plate 1. Anthropogenic $\mathrm{CO}_{2}$ distribution in the Indian Ocean calculated by the TrOCA method at (a) 250, (b) 700 , (c) 1200 , and (d) $3000 \mathrm{~m}$ depth.

are to forecast the sequestration of anthropogenic $\mathrm{CO}_{2}$ in the Indian Ocean, we need to know precisely the present and future currents and physical and biogeochemical properties and pathways.

\section{PAST AND FUTURE WATER MASS PROPERTIES AND CIRCULATION}

As mentioned in section 2, the main characteristics of the northern Indian Ocean circulation are the strong semiannual reversing monsoon winds that force intense upwellings as well as reversal of surface currents. Consequently, the biogeochemical properties and the marine ecosystems of these waters are highly and seasonally variable [Naqvi et al., 2006; Lévy et al., 2007]. At low latitudes south of the equator, a large volume of relatively fresh and warm water from the Pacific Ocean penetrates into the Indian Ocean via the Indonesian Throughflow in the upper 300 $\mathrm{m}$. As can be seen in Plate 1a, this water with relatively high concentrations of anthropogenic $\mathrm{CO}_{2}$ is one of the important sources of anthropogenic $\mathrm{CO}_{2}$ stored within the Indian Ocean.

As today global warming significantly modifies the physical seawater properties (since we observe a rise in temperature) and forcings, there is no doubt that the ocean circulation in the Indian Ocean will change. As the sea sur- 
face temperature rises, how would the monsoons strength and duration change? Would the strength and frequency of cyclones increase? What would be their impacts on the large populations living in coastal areas? Would variations in freshwater flux affect the circulation? Would the Indonesian Throughflow decrease? All of these variations will affect the anthropogenic $\mathrm{CO}_{2}$ penetration into and storage in the Indian Ocean. In turn, they will affect the marine ecosystem, which, in turn, will greatly affect the human food supply.

\section{ANTHROPOGENIC IMPACTS}

Today the concern goes way beyond the penetration of anthropogenic $\mathrm{CO}_{2}$ into the ocean or the temperature rise of the latter. The truly justified concern is about humanity. How will all these changes provoked by humankind on the unique planet Earth affect all human populations (mainly in terms of food and water supply, health, and shelter in coastal areas)?

There is no doubt that the penetration of massive anthropogenic $\mathrm{CO}_{2}$ into the ocean either through $\mathrm{CO}_{2}$ fluxes across the air-sea interface or through river runoff will acidify the seawater. As the chemical properties and nutrient supply in the upper ocean layers are modified, the complete marine ecosystem is at risk. For instance, according to the level of acidification of seawater, some fish species (including shellfish, i.e., clams and mussels) could manifest some deformities before simply disappearing. As an ecosystem is disturbed, it is the whole marine food web that is affected, thus impacting the human food supply.

Since land bordering the northern Indian Ocean is heavily populated and provides major river runoff to the sea, the Indian Ocean is one of the places that urgently need to be intensely studied to anticipate and perhaps prevent major ecological and human disasters.

\section{CONCLUSION}

The Indian Ocean, compared with the Atlantic and Pacific oceans, is relatively small, and its northern basin is bordered by land south of the Tropic of Cancer. This relatively small sea is very sensitive to changes because of anthropogenic forcings.

As we have shown, the Arabian Sea and the Bay of Bengal play contrasting roles in the absorption and storage of anthropogenic carbon from the atmosphere. The Bay of Bengal absorbs more $\mathrm{CO}_{2}$ from the atmosphere than the Arabian Sea, which releases it to the atmosphere. Yet it is the Arabian Sea that sequesters about twice as much carbon as the Bay of Bengal because of water circulation. Most of the anthropogenic $\mathrm{CO}_{2}$ in the Indian Ocean is located in the upper
$1200 \mathrm{~m}$ between $30^{\circ} \mathrm{S}$ and $50^{\circ} \mathrm{S}$, especially in the eastern part of the basin.

In light of this current knowledge, the three main challenges scientists are facing today are (1) to determine the most appropriate approach to quantify anthropogenic $\mathrm{CO}_{2}$ concentrations in the Indian Ocean, (2) to determine the spatiotemporal variations of the $\mathrm{CO}_{2}$ fluxes across the oceanatmosphere interface, and (3) to determine the impacts of global warming on the water properties and circulation.

In order to unravel quickly the potential impacts of anthropogenic $\mathrm{CO}_{2}$ penetration into the Indian Ocean, both in terms of climate change and in terms of ecological variability, there is a critical need to intensify international marine studies throughout the Indian Ocean. Cruises need to be designed not only to quantify the air-sea $\mathrm{CO}_{2}$ fluxes and their impacts on ecological systems in the upper ocean but also throughout the whole water column where anthropogenic $\mathrm{CO}_{2}$ is sequestered before in part either upwelling to the surface (in the Arabian Sea) or sinking farther down (south of $30^{\circ} \mathrm{S}$ ). Such research expeditions should be integrated with concurrent complementary studies of ocean circulation and biogeochemical processes using the newly available research technologies (floats, satellites, chemical sensors, etc.). Such international programs would help to save the beauty and biodiversity of the Indian Ocean for the benefit of humankind.

Acknowledgments. We thank each person that contributed in one way or another to the current GLODAP database. We also thank Karl Banse for comments on our first draft.

\section{REFERENCES}

Bates, N. R., A. C. Pequignet, and C. L. Sabine (2006), Ocean carbon cycling in the Indian Ocean: 1 . Spatiotemporal variability of inorganic carbon and air-sea $\mathrm{CO}_{2}$ gas exchange, Global Biogeochem. Cycles, 20, GB3020, doi:10.1029/2005GB002491.

Bréviére, E., N. Metzl, A. Poisson, and B. Tilbrook (2006), Changes of the oceanic $\mathrm{CO}_{2}$ sink in the eastern Indian sector of the Southern Ocean, Tellus, Ser. B, 58, 438-446.

Brewer, P. G. (1978), Direct observations of the oceanic $\mathrm{CO}_{2}$ increase, Geophys. Res. Lett., 5, 997-1000.

Broecker, W. S., T. Takahashi, and T.-H. Peng (1985), Reconstruction of past atmospheric $\mathrm{CO}_{2}$ from the chemistry of the contemporary ocean: An evaluation, Tech. Rep. TRO 20, U.S. Dep. of Energy, Washington, D. C.

Chen, C. T. A. (1993), The oceanic anthropogenic $\mathrm{CO}_{2}$ sink, Chemosphere, 27, 1041-1067.

Chen, C. T. A., and F. J. Millero (1979), Gradual increase of oceanic carbon dioxide, Nature, 277, 205-206.

Coatanoan, C., C. Goyet, N. Gruber, C. L. Sabine, and M. Warner (2001), Comparison of two approaches to quantify anthropogenic 
carbon in the ocean: Results from the northern Indian ocean, Global Biogeochem. Cycles, 15, 11-25.

Friis, P. (2006), A review of marine anthropogenic $\mathrm{CO}_{2}$ definitions: Introducing a thermodynamic approach based on observations, Tellus, Ser. B, 58, 2-15, doi:10.1111/j.1600-0889.2005.00173.x.

Gerber, M., F. Joos, M. Vázquez-Rodríguez, F. Touratier, and C. Goyet (2009), Regional air-sea fluxes of anthropogenic carbon inferred with an Ensemble Kalman Filter, Global Biogeochem. Cycles, 23, GB1013, doi:10.1029/2008GB003247.

Goyet, C., and P. G. Brewer (1993), Biochemical properties of the oceanic carbon cycle, in Modelling Oceanic Climate Interactions, NATO ASI Ser., Ser. I, vol. 11, edited by J. Willebrand and D. L. T. Anderson, pp. 271-297, Springer, Berlin.

Goyet, C., C. Beauverger, C. Brunet, and A. Poisson (1991), Distribution of carbon dioxide partial pressure in surface waters of the southwest Indian Ocean, Tellus, Ser. B, 43, 1-11.

Goyet, C., N. Metzl, F. Millero, G. Eischeid, D. O'Sullivan, and A. Poisson (1998), Temporal variation of the sea surface $\mathrm{CO}_{2}$ /carbonate properties in the Arabian Sea, Mar. Chem., 63, 69-79.

Goyet, C., C. Coatanoan, G. Eischeid, T. Amaoka, K. Okuda, R. Healy, and S. Tsunogai (1999), Spatial variation of total $\mathrm{CO}_{2}$ and total alkalinity in the northern Indian Ocean: A novel approach for the quantification of anthropogenic $\mathrm{CO}_{2}$ in seawater, J. Mar. Res., 57, 135-163.

Gruber, N. (1998), Anthropogenic $\mathrm{CO}_{2}$ in the Atlantic Ocean, Global Biogeochem. Cycles, 12, 165-191.

Gruber, N., J. L. Sarmiento, and T. F. Stocker (1996), An improved method for detecting anthropogenic $\mathrm{CO}_{2}$ in the oceans, Global Biogeochem. Cycles, 10, 809-837.

Hanawa, K., and L. D. Talley (2001), Mode waters, in Ocean Circulation and Climate, Int. Geophys. Ser., vol. 77, edited by G. Siedler, J. Church, and J. Gould, pp. 373-386, Academic, San Diego, Calif.

Hoppema, M., W. Roether, R. G. J. Bellerby, and H. J. W. De Baar (2001), Direct measurements reveal insignificant storage of anthropogenic $\mathrm{CO}_{2}$ in the abyssal Weddell Sea, Geophys. Res. Lett., 28, 1747-1750

Key, R. M., A. Kozyr, C. L. Sabine, K. Lee, R. Wanninkhof, J. L. Bullister, R. A. Feely, F. J. Millero, C. Mordy, and T.-H. Peng (2004), A global ocean carbon climatology: Results from Global Data Analysis Project (GLODAP), Global Biogeochem. Cycles, 18, GB4031, doi:10.1029/2004GB002247.

Lévy, M., D. Shankar, J. M. André, S. S. C. Shenoi, F. Durand, and C. de Boyer Montégut (2007), Basin-wide seasonal evolution of the Indian Ocean's phytoplankton blooms, J. Geophys. Res., 112, C12014, doi:10.1029/2007JC004090.

Lo Monaco, C., N. Metzl, A. Poisson, C. Brunet, and B. Schauer (2005a), Anthropogenic $\mathrm{CO}_{2}$ in the Southern Ocean: Distribution and inventory at the Indian-Atlantic boundary (World Ocean Circulation Experiment line I6), J. Geophys. Res., 110, C06010, doi:10.1029/2004JC002643.

Lo Monaco, C., C. Goyet, N. Metzl, A. Poisson, and F. Touratier (2005b), Distribution and inventory of anthropogenic $\mathrm{CO}_{2}$ in the Southern Ocean: Comparison of three data-based methods, $J$. Geophys. Res., 110, C09S02, doi:10.1029/2004JC002571.
McCartney, M. (1977), Subantarctic mode water, in A Voyage of Discovery, edited by M. V. Angel, pp. 103-119, Pergamon, Oxford, U. K.

McNeil, B. I., N. Metzl, R. M. Key, R. J. Matear, and A. Corbiere (2007), An empirical estimate of the Southern Ocean air-sea $\mathrm{CO}_{2}$ flux, Global Biogeochem. Cycles, 21, GB3011, doi:10.1029/ 2007GB002991.

Mecking, S., and M. J. Warner (1999), Ventilation of Red Sea Water with respect to chlorofluorocarbons, J. Geophys. Res., 104, 11,087-11,097.

Meredith, M. P., A. J. Watson, K. A. Van Scoy, and T. W. N. Haine (2001), Chlorofluorocarbon-derived formation rates of the deep and bottom waters of the Weddell Sea, J. Geophys. Res., 106, 2899-2919.

Metzl, N., C. Beauverger, C. Brunet, C. Goyet, and A. Poisson (1991), Surface water $p \mathrm{CO}_{2}$ in the western Indian sector of the southern ocean: A highly variable $\mathrm{CO}_{2}$ source/sink region during the summer season, Mar. Chem., 35, 85-95.

Mikaloff-Fletcher, S. E., et al. (2006), Inverse estimates of anthropogenic $\mathrm{CO}_{2}$ uptake, transport, and storage by the ocean, Global Biogeochem. Cycles, 20, GB2002, doi:10.1029/2005GB002530.

Millero, F. J., E. A. Degler, D. W. O'Sullivan, C. Goyet, and G. Eischeid (1998), The carbon dioxide system in the Arabian Sea, Deep Sea Res., Part II, 45(10-11), 2225-2252.

Naqvi, S. W. A., H. W. Bange, S. W. Gibb, C. Goyet, A. D. Hatton, and R. C. Upstill-Goddard (2005), Biogeochemical oceanatmosphere transfers in the Arabian Sea, Prog. Oceanogr., 65, 116-144.

Naqvi, S. W. A., P. V. Narvekar, and E. Desa (2006), Coastal biogeochemical processes in the North Indian Ocean, in The Sea, vol. 14, edited by A. Robinson and K. Brink, pp. 723-780, Harvard Univ. Press, Cambridge, Mass.

Orr, J. E., et al. (2001), Estimates of anthropogenic carbon uptake from four three-dimensional global ocean models, Global Biogeochem. Cycles, 15, 43-60

Orsi, A. H., W. M. Smethie Jr., and J. L. Bullister (2002), On the total input of Antarctic waters to the deep ocean: A preliminary estimate from chlorofluorocarbon measurements, J. Geophys. Res., 107(C8), 3122, doi:10.1029/2001JC000976.

Papaud, A., and A. Poisson (1986), Distribution of dissolved $\mathrm{CO}_{2}$ in the Red Sea and correlation with other geochemical tracers, $J$. Mar. Res., 44, 385-402.

Pérez, F. F., M. Alvarez, and A. F. Rios (2002), Improvements on the back-calculation technique for estimating anthropogenic $\mathrm{CO}_{2}$, Deep Sea Res., Part I, 49, 859-875.

Poisson, A., and C.-T. A. Chen (1987), Why is there little anthropogenic $\mathrm{CO}_{2}$ in the Antarctic Bottom Water?, Deep Sea Res. Part A, 34, 1255-1275.

Sabine, C. L., et al. (2004), The oceanic sink for anthropogenic $\mathrm{CO}_{2}$, Science, 305, 367-371.

Sallée, J. B., N. Wienders, R. Morrow, and K. Speer (2006), Formation of subantarctic mode water in the southeastern Indian Ocean, Ocean Dyn., 56, 525-542.

Sandrini, S., N. Ait-Ameur, P. Rivaro, S. Massolo, F. Touratier, L. Tositti, and C. Goyet (2007), Anthropogenic carbon distribution in the Ross Sea, Antarctica, Antarct. Sci., 19, 395-407. 
Schott, F. A., and J. P. McCreary (2001), The monsoon circulation in the Indian Ocean, Prog. Oceanogr., 51, 1-123.

Shiller, A. M. (1981), Calculating the oceanic $\mathrm{CO}_{2}$ increase: A need for caution, J. Geophys. Res., 86, 11,083-11,088.

Sloyan, B. M., and S. R. Rintoul (2001), Circulation, renewal, and modification of Antarctic Mode and Intermediate Water, J. Phys. Oceanogr., 31, 1005-1030.

Talley, L. D. (1996), Antarctic Intermediate Water in the South Atlantic, in The South Atlantic: Present and Past Circulation, edited by G. Wefer et al., pp. 219-238, Springer, Berlin.

Tanhua, T., D. W. Waugh, and D. W. R. Wallace (2008), Use of $\mathrm{SF}_{6}$ to estimate anthropogenic $\mathrm{CO}_{2}$ in the upper ocean, $J$. Geophys. Res., 113, C04037, doi:10.1029/2007JC004416.

Touratier, F., and C. Goyet (2004a), Definition, properties, and Atlantic distribution of the new tracer TrOCA, J. Mar. Syst., 46, 169-179.

Touratier, F., and C. Goyet (2004b), Applying the new TrOCA approach to assess the distribution of anthropogenic $\mathrm{CO}_{2}$ in the Atlantic Ocean, J. Mar. Syst., 46, 181-197.

Touratier, F., L. Azouzi, and C. Goyet (2007), CFC-11, $\Delta{ }^{14} \mathrm{C}$ and ${ }^{3} \mathrm{H}$ tracers as a means to assess anthropogenic $\mathrm{CO}_{2}$ concentrations in the ocean, Tellus, Ser. B, 59, 318-325.
Vázquez-Rodríguez, M., F. Touratier, C. Lo Monaco, D. W. Waugh, X. A. Padin, R. G. J. Bellerby, C. Goyet, N. Metzl, A. F. Rios, and F. F. Pérez (2009), Anthropogenic carbon distributions in the Atlantic Ocean: Data-based estimates from the Arctic to the Antarctic, Biogeosciences, in press.

Wanninkhof, R., S. C. Doney, T. H. Peng, J. L. Bullister, K. Lee, and R. A. Feely (1999), Comparison of methods to determine the anthropogenic $\mathrm{CO}_{2}$ invasion into the Atlantic Ocean, Tellus, Ser. B, 51, 511-530.

Waugh, D. W., T. W. N. Haine, and T. M. Hall (2004), Transport times and anthropogenic carbon in the subpolar North Atlantic Ocean, Deep Sea Res., Part I, 51, 1475-1491.

Waugh, D. W., T. M. Hall, B. I. McNeil, R. Key, and R. J. Matear (2006), Anthropogenic $\mathrm{CO}_{2}$ in the oceans estimated using transit time distributions, Tellus, Ser. B, 58, 376-389.

C. Goyet and F. Touratier, IMAGES, Université de Perpignan, 52 avenue Paul Alduy, F-66860 Perpignan, France. (cgoyet@ univ-perp.fr) 
